\title{
Resistance to Bacterial Canker in Tomato (Lycopersicon hirsutum LA407) and its Progeny Derived from Crosses to L. esculentum
}

\author{
David M. Francis and Eileen Kabelka, Department of Horticulture and Crop Science, Ohio Agricultural Research \\ and Development Center, Wooster 44691; Julia Bell, Department of Botany and Plant Pathology, Michigan State \\ University, East Lansing 48824; Barb Franchino, Department of Horticulture and Crop Science, Ohio Agricultural \\ Research and Development Center; and Dina St. Clair, Department of Vegetable Crops, University of California, \\ Davis 95616
}

\begin{abstract}
Francis, D. M., Kabelka, E., Bell, J., Franchino, B., and St. Clair, D. 2001. Resistance to bacterial canker in tomato (Lycopersicon hirsutum LA407) and its progeny derived from crosses to $L$. esculentum. Plant Dis. 85:1171-1176.

Bacterial canker caused by Clavibacter michiganensis subsp. michiganensis causes significant yield losses on tomatoes grown in a humid environment. This study was conducted to identify a source of resistance that could be easily crossed to cultivated tomato and to study the inheritance of resistance. Diverse bacterial strains representative of the major DNA fingerprint classes endemic to North America were used to screen germ plasm and populations derived from wide crosses. Partial resistance to genetically characterized and distinct strains of C. michiganensis subsp. michiganensis was identified in a wild relative of cultivated tomato, Lycopersicon hirsutum Lycopersicon accession (LA)407. The level of resistance in LA407 was not significantly different from that of the resistant $L$. peruvianum control, LA2157. Resistance from LA407 was recovered in lines from a $\mathrm{BC}_{2} \mathrm{~S}_{4}$ inbred backcross (IBC) population in both greenhouse and field trials. Linear correlations between field and greenhouse resistance scores were significant, though correlation coefficients tended to be low. Variance components for genetic and environmental variation in resistance were used to estimate broad-sense heritability in the IBC population. These estimates were moderate to high, ranging from 0.34 to 0.85 . The number of genes contributing to resistance was estimated from four trials, with most estimates falling in the range of one to three loci. Two lines from the IBC population, IBL 2353 and IBL 2361 , were identified as sources that retain resistance in a genetic background that has a theoretical L. esculentum genome content of $87.5 \%$.
\end{abstract}

Additional keywords: inbred backcross

Bacterial canker of tomato caused by Clavibacter michiganensis subsp. michiganensis is a significant problem on tomatoes cultivated in a humid environment and is increasing where greenhouse-grown transplants are replacing direct seeding to establish field stands. The disease is devastating due to the systemic movement of bacteria in the vascular tissue (20). Estimates of yield loss range from $10 \%$ annual regional losses $(13,28)$ to $84 \%$ for individ-

Corresponding author. D. M. Francis

E-mail francis.77@osu.edu

Salaries and research support were provided by state and federal funds appropriated to The Ohio State University, Ohio Agricultural Research and Development Center, and grant funds from the Mid-America Food Processors.

The mention of firm names or trade products does not imply that they are endorsed or recommended by The Ohio State University over other firms or similar products not mentioned.

Accepted for publication 11 July 2001.

Publication no. D-2001-0905-01R

(C) 2001 The American Phytopathological Society ual growers $(10,28)$. Yield losses attributable to bacterial canker in controlled studies range from 11 to $99 \%(3,6,23)$. Systemic infection can lead to seed infection; therefore, the seed industry invests substantial effort in testing hybrid seed lots for infestation. Despite the importance of bacterial canker, presently there is no reliable control (10).

Historically, much of the research effort aimed at understanding bacterial canker and $C$. michiganensis subsp. michiganensis has focused on techniques for classification and diagnosis $(15,24,25)$. Recent efforts to classify C. michiganensis subsp. michiganensis have implications for resistance breeding. Subspecies typing of C. michiganensis subsp. michiganensis isolates has been possible using the amplification of repetitive DNA elements by polymerase chain reaction (rep-PCR) for DNA fingerprint analysis using "REP", "BOX", and "ERIC" primers (16-18). Four distinct genetic types of $C$. michiganensis subsp. michiganensis, designated A through $\mathrm{D}$, occur in North America (16). Isolates found on processing tomatoes in the Midwest were $95 \%$ type $\mathrm{A}$ and $5 \%$ type $\mathrm{C}$. The diversity and predominance of isolates found in field epidemics is an important consideration in choosing isolates for germ plasm screening and breeding, and has not been considered in previous germ plasm evaluations.

Although several potential sources of resistance to C. michiganensis subsp. michiganensis have been suggested in the literature $(2,27)$, the lack of criteria for typing bacterial isolates and a poor understanding of the genetic basis of resistance have inhibited breeding progress. Traditional breeding approaches in North America have been targeting resistance to bacterial canker for over 25 years (5), yet this work has provided no detailed knowledge of the genetic basis of resistance. The slow development of resistant cultivars may reflect a limited knowledge of the pathogen, a lack of genetic diversity in the isolates used to screen germ plasm, or the breeding strategy. An example follows from studies on resistance to bacterial canker in tomato germ plasm that were described by Berry et al. (2). The isolates used for those studies were recently characterized by rep-PCR and all represent the type $\mathrm{C}$ fingerprint class (C. Medina-Mora and D. Francis, unpublished data), and thus do not accurately represent the diversity found in the endemic population of $C$. michiganensis subsp. michiganensis.

More recent studies report progress in characterizing the genetic basis of resistance. Observations of resistance or tolerance in cultivated tomato and closely related germ plasm (e.g., Hawaii 7998) suggest that resistance involves multiple loci (21). The best characterized source of resistance is found in Lycopersicon peruvianum Lycopersicon accession (LA)2157, and involves a minimum of three to five loci based on linkage to molecular markers $(26,29)$. Crosses between cultivated tomato and $L$. peruvianum require tissue culture procedures to rescue hybrid and backcross embryos or ovules. It may be difficult to transfer three to five loci for resistance from $L$. peruvianum into a cultivated tomato given the complex inheritance of fruit quality factors and yield that are essential in a commercial cultivar. In addition, the strains used to study resistance in LA2157 have not been characterized by rep-PCR, and it is unclear how representative they are of strains causing epidemics. 
Successful breeding for resistance will be favored by the use of genetically characterized $C$. michiganensis subsp. michiganensis strains, sources of resistance that can be easily crossed with $L$. esculentum cultivars, and populations that facilitate the introgression of quantitative traits. The objectives of this study were to identify new sources of resistance to bacterial canker using strains of $C$. michiganensis subsp. michiganensis that have been genetically defined using rep-PCR and to test our ability to recover resistant progeny. To meet the goals of the second objective, an inbred backcross (IBC) breeding population (30), developed by crossing $L$. hirsutum LA407 to cultivated tomato, was evaluated. The IBC population provided a means to introgress resistance into a $L$. esculentum processing tomato background, uting to resistance, and to estimate the broad-sense heritability of resistance.

\section{MATERIALS AND METHODS}

Experimental design. We conducted three replicated experiments to identify potential sources of resistance to bacterial canker and to confirm that the resistance would be inherited in progeny. The first experiment consisted of a greenhouse evaluation of three L. esculentum cultivars, two L. pimpinellifolium accessions, two $L$. cheesmanii accessions, two $L$. pennellii accessions, two L. hirsutum accessions, and one L. peruvianum accession (Table 1). The 12 cultivars and accessions were included in a completely randomized design with three to four plants per genotype. The experiment was replicated twice using three different strains as treatments. Strains of $C$. michiganensis subsp. michiganensis were chosen to represent three predominant DNA fingerprint types of C. michiganensis subsp. michiganensis (16). To verify resistance in a single wild accession, to approximate the number of loci contrib-

L. hirsutum LA407, a second experiment was conducted using 12 strains representing the three predominant DNA fingerprint types of $C$. michiganensis subsp. michiganensis (16). This experiment was replicated twice and each replicate included three to four plants per bacterial strain using a completely random design. Finally, a third experiment was conducted in order to confirm a genetic basis for the resistance observed in the first two experiments. For this experiment, segregating populations consisting of homozygous lines were evaluated in four trials, two in the greenhouse and two in the field. Greenhouse trials used a completely randomized design with two to three plants of each line per inoculation. Field trials used a randomized complete block design with three blocks. Two strains of $C$. michiganensis subsp. michiganensis that represent the most predominant of the DNA fingerprint types (A and $\mathrm{C}$ ) were used in separate inoculations, such that each strain was represented in a single greenhouse and field trial with segregating populations.

Plant material. Criteria for selecting tomato germ plasm for evaluation of resistance included the availability of previously developed populations for genetic mapping or breeding (e.g., recombinant inbred populations, segmental substitution lines, and inbred backcross populations), previous observations of resistance or tolerance by tomato breeders, and suitable genetic polymorphism. The L. peruvianum accession LA2157 was included as a resistant control in germ plasm evaluations. The commercial cultivar Heinz 9144 was reported to have resistance to bacterial canker derived from Bulgaria 12 (22) and was included as a resistant control during the evaluation of segregating populations. Two additional controls, Ohio 97743 and Ohio 97744, were included based on breeders' observations of partial resistance (D. Fran-

Table 1. Disease severity (rated 0 to 5) to three Clavibacter michiganensis subsp. michiganensis strains in diverse tomato (Lycopersicon spp.) germ plasm

\begin{tabular}{|c|c|c|c|c|}
\hline \multirow[b]{2}{*}{ Genotype } & \multirow[b]{2}{*}{ Species } & \multicolumn{3}{|c|}{$\operatorname{Mean}^{x}$} \\
\hline & & Strain $300(A)^{y}$ & Strain 68 (B) & Strain $290(C)$ \\
\hline H8704 & L. esculentum & $5.00 \mathrm{a}$ & $4.50 \mathrm{a}$ & $5.00 \mathrm{a}$ \\
\hline Ha7998 & L. esculentum & $4.00 \mathrm{~b}$ & $4.33 \mathrm{a}$ & $4.25 \mathrm{~b}$ \\
\hline Ha7981 & L. esculentum & $3.25 \mathrm{c}$ & $3.00 \mathrm{bc}$ & $3.00 \mathrm{c}$ \\
\hline PI126445 & L. hirsutum & $2.50 \mathrm{~d}$ & ND & $2.33 \mathrm{~cd}$ \\
\hline PI128216 & L. pimpinellifolium & $2.50 \mathrm{~d}$ & $2.00 \mathrm{~cd}$ & $2.50 \mathrm{~cd}$ \\
\hline LA442 & L. pimpinellifolium & $2.33 \mathrm{~d}$ & $3.33 \mathrm{ab}$ & $2.67 \mathrm{~cd}$ \\
\hline LA528 & L. cheesmanii & $2.33 \mathrm{~d}$ & ND & $2.50 \mathrm{~cd}$ \\
\hline LA716 & L. pennellii & $2.00 \mathrm{~d}$ & $1.00 \mathrm{~d}$ & $2.00 \mathrm{~d}$ \\
\hline LA750 & L. pennellii & $2.00 \mathrm{~d}$ & $2.67 \mathrm{~cd}$ & $2.50 \mathrm{~cd}$ \\
\hline LA422 & L. cheesmanii & $2.00 \mathrm{~d}$ & ND & $2.00 \mathrm{~d}$ \\
\hline LA407 & L. hirsutum & $1.00 \mathrm{e}$ & $2.33 \mathrm{~cd}$ & $1.00 \mathrm{e}$ \\
\hline LA2157 & L. peruvianum & $0.33 \mathrm{f}$ & $2.00 \mathrm{~cd}$ & $0.33 \mathrm{e}$ \\
\hline LSD $0.05^{z}$ & $\ldots$ & 0.66 & 1.21 & 0.79 \\
\hline
\end{tabular}

${ }^{x}$ Mean disease severity on a scale of 0 (no symptoms) to 5 (dead plant). Mean separations were performed after a significant analysis of variance using a two-tailed $T$ test. Means followed by the same letter are not significantly different at $P=0.05 ; \mathrm{ND}=$ not determined.

${ }^{y}$ Letter following strain number indicates repetitive DNA-polymerase chain reaction fingerprint class (16).

${ }^{\mathrm{z}}$ Least significant difference. cis, unpublished data). Stock seed for all plant introduction (PI) lines was obtained through the United States Department of Agriculture-Agricultural Research Service Plant Introduction Center, Geneva, NY. The Tomato Genetics Stock Center, Davis, CA provided all Lycopersicon accession (LA) germ plasm. Commercial sources were used for Heinz Seed cultivars, and cultivars designated $\mathrm{O}$ for Ohio and $\mathrm{Ha}$ for Hawaii were from the Ohio Agricultural Research and Development Center germ plasm collection.

Segregating populations for LA716 and LA407 have been described in detail previously $(7,14)$. Both populations contain inbred lines with the wild species genome introgresed into a L. esculentum processing tomato background. Each line in the LA716 segmental substitution population contains a distinct single introgression from the wild $L$. pennellii donor. The complete donor genome is represented in the 51 lines that make up the population. The LA407 IBC breeding population consists of $64 \mathrm{BC}_{2} \mathrm{~S}_{4}$ lines developed by crossing $L$. hirsutum LA407 to Hunt 100 followed by a backcross to Hunt 100. Individual $\mathrm{BC}_{1}$ lines were crossed to Peto $95-43 ; \mathrm{BC}_{2}$ lines were then advanced by self-fertilization and single seed descent four generations. Each line in the LA407 IBC population has a theoretical L. esculentum contribution of $87.5 \%$. The remaining $12.5 \%$ of the genome represents random introgressions from the donor, LA407, which have been fixed by inbreeding.

Pathogen strains. C. michiganensis subsp. michiganensis strains belonging to BOX-PCR fingerprint type A (strain number 300); fingerprint type B (strain number 68 ), and fingerprint type $C$ (strain number 290) were used for the first experiment (16). Resistance in L. hirsutum LA407 was confirmed in a second experiment using multiple strains belonging to BOX-PCR fingerprint type A (strain numbers 253, 291, 299, and 300); fingerprint type B (strain numbers 12, 30, 68, and 226), and fingerprint type C (strain numbers 21,38 , 115, and 290). Strains A300 and C290 were used to confirm resistance in the $L$. hirsutum LA407 IBC population in the third experiment. All strains of C. michiganensis subsp. michiganensis were determined to be aggressive based on previous inoculation.

Greenhouse inoculation. Plants grown from seed were kept in a greenhouse under conditions previously described (16). Bacterial cultures were prepared and inoculations were performed as described in Louws et al. (16). Briefly, C. michiganensis subsp. michiganensis cultures were adjusted to approximately $3 \times 10^{8}$ $\mathrm{CFU} / \mathrm{ml}$. The petiole of the first true leaf of a seedling was severed with scissors dipped in the bacterial suspensions.

Inoculated plants were observed for symptom development for 8 to 12 weeks. 
Individual disease rating scores (IDRS) were based on visual assessment of symptom severity using an additive disease rating scale of 0 to 5 . A score of 0 represented no symptoms and one point was assigned for each of the following symptoms: marginal necrosis, wilt, and canker. A half-point was deducted if symptoms were mild and a half point was added if symptoms are severe. Using this system, a plant with severe necrosis, wilt, and canker received an IDRS of 4.5 and a plant with mild necrosis, wilt, and canker received an IDRS of 1.5. Dead plants were rated 5 . Here we reported the IDRS when the experiment or trial reached maximal disease.

Disease progression was assessed on the basis of percent maximal disease (PMD), which is similar to area under the disease progression curve (AUDPC), with the 0-to5 scale adjusted to 0 to $100 \%$. This approach allowed an estimate of disease severity for each replicate of an experiment and permitted comparison of genotypes across experiments. The formula for PMD was

$$
\mathrm{PMD}=\frac{100 \sum_{i=1}^{n-1}\left[\left(D_{i}+D_{i+1}\right) / 2\right]\left[T_{i+1}-T_{i}\right]}{\left[T_{n}-T_{1}\right] M}
$$

where $n=$ total number of observations, $D_{i}$ $=$ individual disease rating score at $i$ th observation, $T_{i}=$ time (days) at $i$ th observation, and $M=$ maximum score of disease rating scale.

At the end of the first two greenhouse experiments, a $1-\mathrm{cm}$ segment of the stem $10 \mathrm{~cm}$ above the inoculation site was removed and stored at $-20^{\circ} \mathrm{C}$. Each stem

Table 2. Disease severity (rated 0 to 5) and bacterial populations in LA407 when challenged with multiple strains

\begin{tabular}{|c|c|c|c|}
\hline Strain & Class $^{w}$ & $\begin{array}{l}\text { Mean } \\
\text { score }^{x}\end{array}$ & $\begin{array}{c}\text { Log } \\
\text { titer }^{y}\end{array}$ \\
\hline 12 & B & 1.30 & 5.28 \\
\hline 21 & B & 1.80 & 2.66 \\
\hline 30 & $\mathrm{C}$ & 1.60 & 5.01 \\
\hline 38 & C & 1.80 & 5.28 \\
\hline 68 & B & 1.20 & 6.63 \\
\hline 115 & $\mathrm{C}$ & 1.00 & 5.15 \\
\hline 226 & B & 1.00 & 5.62 \\
\hline 253 & A & 1.00 & 5.26 \\
\hline 290 & $\mathrm{C}$ & 1.80 & 6.77 \\
\hline 291 & A & 1.80 & 4.64 \\
\hline 299 & A & 1.70 & 4.91 \\
\hline 300 & A & 1.40 & 4.29 \\
\hline Mean & $\ldots$ & 1.47 & 5.12 \\
\hline LSD $0.05^{z}$ & $\ldots$ & 1.12 & 2.75 \\
\hline
\end{tabular}

${ }^{\mathrm{w}}$ Class indicates repetitive DNA-polymerase chain reaction fingerprint class (16) for the strains used.

${ }^{x}$ Mean disease severity on a scale of 0 (no symptoms) to 5 (dead plant). Means are not significantly different at $P=0.05$.

y Base ten logarithm of bacterial populations determined by counting CFU after serial dilution. Strain B21 differed $(P=0.05)$ from the other isolates and appeared to accumulate a smaller population in the resistant host.

${ }^{\mathrm{z}}$ Least significant difference. segment was weighed and crushed in two volumes of $10 \mathrm{mM}$ potassium phosphate buffer ( $\mathrm{pH}$ 7.4). The resulting suspensions were subjected to 10 -fold serial dilution, and $0.1-\mathrm{ml}$ aliquots were spread on agar plates containing nutrient broth yeast extract media modified by omitting glucose (MNBY; 12). The number of CFU was determined after 5 days of incubation at room temperature.

Field inoculation. Seedlings were inoculated with $C$. michiganensis subsp. michiganensis in the greenhouse prior to transplant to mimic the epidemiology of the disease (12). Seeds were sown in 288cell flats and grown for 4 to 6 weeks post germination. Seedlings were sprayed to run off with a suspension of 1 to $3 \times 10^{8} \mathrm{CFU}$ of bacteria per milliliter of water using a Preval Sprayer (Percision Value Corporation, Yonkers, NY) 1 week prior to transplant. Field trials were established using a randomized complete block design with two blocks (1997) or three blocks (1998) per trial. Plots consisted of 10 plants spaced $30 \mathrm{~cm}$ apart. Disease score and disease development was assessed using the 0-to-5 scale and PMD described above, with ratings based on plot averages. Evaluation of resistance to $C$. michiganensis subsp. michiganensis type C (C290) and type A (A300) strains was conducted in separate years (1997 and 1998, respectively). Disease severity was rated once per week for 8 weeks after initial symptom development was observed in susceptible controls.

Statistical analysis. Analysis of variance (ANOVA) and mean comparisons of germ plasm and segregating populations were performed with the SAS general linear models (GLM) procedure. Means were obtained with the least-squared means (lsmeans) statement to compensate for unequal numbers (three or four) of plants in the first two experiments. Mean separations used the experiment-wise error and were preformed only after a significant $F$ test from the ANOVA. Linear correlations of means between experiments (greenhouse to field and strain to strain) were calculated using the CORR procedure. Heritability estimates were obtained by partitioning variation and obtaining mean square estimates for genotype, replicate, and error. Mixed-model analyses of variance was used to obtain mean square estimates using the procedure MIXED with restricted maximum likelihood estimation (REML) specified. Degrees of freedom were calculated via the Satterthwaite option (19). Because replication of the greenhouse and field experiments were confounded by $C$. michiganensis subsp. michiganensis strains, the relationship $\mathrm{H}=$ $\sigma_{\mathrm{G}}^{2} /\left[\sigma_{\mathrm{G}}^{2}+\left(\sigma_{\mathrm{E}}^{2}\right) / \mathrm{rep}\right]$ was used to estimate broad sense heritability for each experiment separately according to Cotterill (4), and standard errors for heritability were calculated according to Hallauer and
Miranda (11). Estimates of the number of genes in the IBC population were obtained using the approach of Eskridge and Coyne (8).

\section{RESULTS}

In the first experiment, no significant variation was attributed to experimental replication or pathogen strain (treatment). Tomato genotype was highly significant $(P$ $<0.01$ ) and mean separations revealed that several wild species accessions were more resistant than the susceptible check, H8704 (Table 1). The L. hirsutum accession LA407 was not significantly different from the previously described resistant check, LA2157 (26) with strains B68 and C290. LA407 was only slightly less resistant than LA2157 when A300 was used for inoculation.

To verify that the resistance in LA407 would prove effective against endemic populations of $C$. michiganensis subsp. michiganensis, multiple strains of each fingerprint type were used in a second experiment. ANOVA based on the 6-week rating period (where maximal disease was reached) and PMD suggested little replicate-to-replicate variation, and results for both replicates of the second experiment were pooled for presentation in Table 2. All susceptible control plants had both severe necrosis at the site of inoculation and wilt 6 weeks after inoculation with all strains in both replicates (data not shown). Very little significant variation could be attributed to either strain or fingerprint class in these analyses. Three strains were common to experiments 1 and 2. The severity values for strains $\mathrm{A} 300, \mathrm{~B} 68$, and C290 were $1.00,2.33$, and 1.00 , respectively in experiment 1 (Table 1) and 1.40 , 1.20 , and 1.80 , respectively, for experiment 2 (Table 2). These values do not differ significantly due to the variation associated with replicates within experiments and variation between experiments. Symptom development was variable, as were pathogen population sizes above the point of inoculation. Some LA407 plants exhibited the development of secondary cankers above the site of inoculation. Pathogen population sizes were variable even among LA407 plants exhibiting similar symptom development; these population sizes ranged from $<2 \times 10^{3}$ to $1 \times 10^{9} \mathrm{CFU} / \mathrm{g}$. Pathogen population sizes in eight susceptible control plants were less variable and ranged from 1.1 to $2.1 \times 10^{9} \mathrm{CFU} / \mathrm{ml}$. Variable symptom expression and a reduction in bacterial populations suggested that resistance is subject to environmental variation.

In order to confirm a genetic basis for the partial resistance observed in the first two experiments, segregating populations developed using LA716 and LA407 were analyzed. Both populations are inbred and each line retains a small and distinct portion of the wild donor genome in a processing tomato background. These popula- 
Table 3. Average disease rating in field trials for selected inbred backcross lines inoculated with two Clavibacter michiganensis subsp. michiganensis strains ${ }^{\mathrm{w}}$

\begin{tabular}{llll}
\hline Strain, genotype & Description & IDRS $^{\mathbf{y}}$ & PMD $^{\mathbf{z}}$ \\
\hline Strain A360 & & & \\
88119 & S control & $3.87 \mathrm{e}$ & $50.14 \mathrm{f}$ \\
97744 & R control & $3.79 \mathrm{e}$ & $46.54 \mathrm{f}$ \\
2314 & IBC line & $3.75 \mathrm{de}$ & $45.76 \mathrm{f}$ \\
8245 & S control & $3.75 \mathrm{de}$ & $48.01 \mathrm{f}$ \\
97743 & R control & $3.71 \mathrm{cde}$ & $47.19 \mathrm{f}$ \\
86120 & S control & $3.69 \mathrm{bcde}$ & $49.15 \mathrm{f}$ \\
2332 & IBC line & $3.69 \mathrm{bcde}$ & $63.67 \mathrm{~g}$ \\
2356 & IBC line & $3.37 \mathrm{abcde}$ & $43.78 \mathrm{ef}$ \\
H9144 & R control & $3.19 \mathrm{abcd}$ & $37.51 \mathrm{de}$ \\
2348 & IBC line & $3.15 \mathrm{abc}$ & $25.36 \mathrm{a}$ \\
2353 & IBC line & $3.13 \mathrm{ab}$ & $26.61 \mathrm{ab}$ \\
2312 & IBC line & $3.03 \mathrm{a}$ & $33.56 \mathrm{bcd}$ \\
2361 & IBC line & $2.97 \mathrm{a}$ & $34.93 \mathrm{~cd}$ \\
2357 & IBC line & $2.81 \mathrm{a}$ & $29.84 \mathrm{abc}$ \\
LSD & & 0.57 & 7.34 \\
IBC population mean & & 3.55 & 43.61 \\
Strain C290 & & & \\
88119 & & $4.25 \mathrm{e}$ & $75.25 \mathrm{f}$ \\
2357 & S control & $3.00 \mathrm{~d}$ & $55.99 \mathrm{e}$ \\
8245 & IBC line & $2.88 \mathrm{~cd}$ & $49.09 \mathrm{bcde}$ \\
2332 & S control & $2.88 \mathrm{~cd}$ & $50.34 \mathrm{cde}$ \\
H9144 & IBC line & $2.75 \mathrm{bcd}$ & $53.14 \mathrm{de}$ \\
97743 & R control & $2.75 \mathrm{bcd}$ & $49.49 \mathrm{cde}$ \\
97744 & R control & $2.63 \mathrm{abcd}$ & $46.57 \mathrm{bcde}$ \\
2312 & R control & $2.50 \mathrm{abcd}$ & $38.03 \mathrm{abc}$ \\
2314 & IBC line & $2.25 \mathrm{abcd}$ & $40.01 \mathrm{abcd}$ \\
2356 & IBC line & $2.25 \mathrm{abcd}$ & $43.12 \mathrm{bcde}$ \\
2348 & IBC line & $2.13 \mathrm{abc}$ & $36.36 \mathrm{abc}$ \\
2361 & IBC line & $2.00 \mathrm{ab}$ & $34.23 \mathrm{ab}$ \\
2353 & IBC line & $1.88 \mathrm{a}$ & $30.90 \mathrm{a}$ \\
LSD 0.05 & IBC line & 0.79 & 14.98 \\
IBC population mean & $\ldots$ & 2.88 & 49.34 \\
\hline & . & & \\
\hline
\end{tabular}

${ }^{\text {w}}$ Mean separations were performed after a significant Genotype effect in the mixed model analysis of variance. A two-tailed $T$ test was used to separate least square means; means followed by the same letter are not significantly different at $P=0.05$.

${ }^{x} \mathrm{~S}=$ susceptible, $\mathrm{R}=$ resistant, $\mathrm{IBC}=$ inbred backcross

${ }^{\text {y }}$ IDRS = individual disease rating scores; mean disease severity on a scale of 0 (no symptoms) to 5 (dead plant).

${ }^{\mathrm{z}} \mathrm{PMD}=$ percent maximal disease, is analogous to area under the disease progression curve.

tions, therefore, favor replicated trials. ANOVA for field and greenhouse trials inoculated with strain C290 revealed significant differences between genotypes (lines) in the LA407 IBC population but not within the LA716 segmental substitution population (data not shown). The LA716 population was, therefore, not included in further trials. Analysis of results for the LA407 IBC population from two greenhouse and two field trials revealed individual LA407 IBC lines that were significantly better than susceptible controls in both field (Table 3) and greenhouse studies (data not shown). Individual lines were occasionally significantly better than the best resistant check, H9144 (Table 3). When field and greenhouse studies were compared, we detected statistically significant positive linear correlations $(0.03>P>$ 0.0001 ) using IDRS values obtained after the third rating period and using PMD. Correlation coefficients ranged from 0.356 to 0.459. Comparisons between trials inoculated with type A and C strains also revealed significant correlations $(0.05>P$ $>0.03$ ), with correlation coefficients ranging between 0.265 and 0.358 . Low correla- tion coefficients may be due to environmental differences from year to year or greenhouse to field, differences in inoculation techniques, differences in strain virulence characteristics, or the quantitative nature of resistance.

Classical genetic analysis was used to estimate gene numbers and broad-sense heritability in the IBC population. Estimates of the number of genes in the IBC population ranged from 1 to 10 genes, with most estimates falling in the range of 1 to 3 (Table 4). Heritability estimates were obtained by partitioning variation and obtaining mean square estimates for genotype, replicate, and error. Replication of the greenhouse and field experiments were confounded by $C$. michiganensis subsp. michiganensis strains; therefore, genotypeyear (GY) and genotype-location (GL) interactions were not included in the estimation of heritability. The estimates in Table 4 represent an overestimate of broad sense heritability because interactions (GY and GL) are included in the mean square estimate for genotype. Estimates of broadsense heritability ranged from 0.34 to 0.85 (Table 4), suggesting that heritability was high to moderate. Estimates were higher for the trials with strain A300 than for trials using C290.

\section{DISCUSSION}

The quantitative nature of resistance from LA407, an inbred accession of $L$. hirsutum, suggests that resistance is partial and subject to environmental variation. The variable symptom expression and detection of bacteria $10 \mathrm{~cm}$ above the inoculation point demonstrate that bacteria reproduce and spread in the resistant host. Despite the ability of C. michiganensis subsp. michiganensis strains to reproduce and move, symptoms and bacterial populations were significantly reduced in LA407 when compared with susceptible checks. The resistance in LA407 appears to be similar in magnitude to the best-characterized source of resistance, L. peruvianum LA2157 $(26,29)$. Resistance from $L$. hirsutum may have several advantages to resistance from L. peruvianum due to the relative ease with which progeny can be generated.

The preliminary characterization of progeny from LA407 described in this article suggests that resistance was conferred by a few genes with moderate to high heritability. Most estimates of gene number fell in the range of one to three. The exception to this estimate, based on maximum disease in the 1997 greenhouse trial, can be attributed to the fact that all susceptible checks died (IDRS $=5.0$ ) while progeny averaged 3.1. Thus, many progeny lines were significantly more resistant than the checks and the estimate of number of loci was high relative to the trials where some checks survived. The heritability estimates reported above should not be considered an accurate representation of breeding value; that is, they will not predict genetic gain under selection. Rather, they represent an upper estimate of the total variation attributable to genotype in these trials, assuming that the selection unit is an individual IBL. The higher heritability estimates for trials with strain A300 reflect smaller error in these experiments, but it is unclear if this is due to differences in virulence or aggressiveness between strains or uncontrolled environmental differences between the experiments.

Characterization of the interaction between C. michiganensis subsp. michiganensis and tomato has not progressed to the point where we can speculate on the importance of strain-to-strain variation in the expression of host resistance. We detected no statistically significant strain-tostrain variation despite selecting strains that represent genetically distinct lineages. The fact that we demonstrate resistance in LA407 to multiple strains of C. michiganensis subsp. michiganensis derived from distinct DNA fingerprint classes suggests that this source of resistance will be useful against the population of bacteria endemic to North America. 
Table 4. Estimates of variance components, gene number, and heritability (broad sense) from the LA407 inbred backcross (IBC)

\begin{tabular}{|c|c|c|c|c|c|c|c|c|}
\hline \multirow[b]{3}{*}{ Trial $^{\mathbf{z}}$} & \multicolumn{4}{|c|}{ Variance component ${ }^{w}$} & & & & \\
\hline & \multicolumn{2}{|c|}{ Genotype } & \multicolumn{2}{|c|}{ Error } & \multicolumn{2}{|c|}{ Gene numberx } & \multicolumn{2}{|c|}{ Heritability $^{\mathrm{y}}$} \\
\hline & Estimate & SE & Estimate & SE & Estimate & SE & Estimate & SE \\
\hline \multicolumn{9}{|l|}{ Field (C-Strain) } \\
\hline PMD & 36.49 & 12.92 & 60.22 & 10.65 & 3.09 & 0.66 & 0.55 & 0.19 \\
\hline IDRS Max. Disease & 0.12 & 0.04 & 0.16 & 0.03 & 2.43 & 0.58 & 0.60 & 0.19 \\
\hline \multicolumn{9}{|l|}{ Greenhouse (C-Strain) } \\
\hline PMD & 17.82 & 10.98 & 69.10 & 10.65 & 0.72 & 0.29 & 0.34 & 0.21 \\
\hline IDRS Max. Disease & 0.58 & 0.19 & 0.16 & 0.03 & 10.16 & 1.57 & 0.57 & 0.19 \\
\hline \multicolumn{9}{|l|}{ Field (A-Strain) } \\
\hline PMD & 35.09 & 7.65 & 20.62 & 2.60 & 2.92 & 0.64 & 0.77 & 0.17 \\
\hline IDRS Max. Disease & 0.08 & 0.02 & 0.13 & 0.02 & 1.67 & 0.46 & 0.56 & 0.16 \\
\hline \multicolumn{9}{|l|}{ Greenhouse (A- } \\
\hline \multicolumn{9}{|l|}{ Strain) } \\
\hline PMD & 173.30 & 37.68 & 20.62 & 2.60 & 0.64 & 0.29 & 0.85 & 0.18 \\
\hline IDRS Max. Disease & 0.54 & 0.12 & 0.21 & 0.04 & 0.64 & 0.29 & 0.84 & 0.18 \\
\hline
\end{tabular}

w Variance components for genotype and residual (error) were estimated using the SAS procedure MIXED with restricted maximum likelihood estimation.

${ }^{x}$ Estimates of the number of genes in the IBC population were obtained using the approach of Eskridge and Coyne (8).

${ }^{y} \mathrm{H}=\sigma_{\mathrm{G}}^{2} /\left[\sigma_{\mathrm{G}}^{2}+\left(\sigma_{\mathrm{E}}^{2}\right) / \mathrm{rep}\right]$ was used to estimate broad sense heritability for each trial separately as described by Cotterill (4) and standard errors calculated according to Hallauer and Miranda (11).

${ }^{\mathrm{z}} \mathrm{PMD}=$ percent maximal disease and IDRS $=$ individual disease rating scores.

The occurrence of a hypersensitive reaction (HR) on four-o'clock (Mirabilis jalapa) inoculated with $C$. michiganensis subsp. michiganensis (9) suggests that an active host response may play a role in determining the outcome of this hostpathogen interaction. The HR can be reproduced with cell-free extracts on both M. jalapa and tobacco (Nicotiana tabacum), a result that has been interpreted to imply that a host reaction similar to the harpin response described from gramnegative bacteria may play a role in defense (1). It is unclear whether these results and interpretations can be extended to the tomato-C. michiganensis subsp. michiganensis interaction. It will be prudent to include multiple pathogen strains that have been genetically characterized for future genetic characterization of resistance from LA407. Including characterized strains will facilitate the identification of specific tomato-C. michiganensis subsp. michiganensis interactions that may have implications for the durability of resistance.

The results reported in this article suggest that the L. hirsutum accession LA407 contains genes that confer resistance to multiple strains in the $\mathrm{A}, \mathrm{B}$, and $\mathrm{C}$ fingerprint class of $C$. michiganensis subsp. michiganensis. Partial resistance to strains A300 and C290 is heritable and can be recovered in individual lines derived using determinate processing tomato genotypes as the recurrent parent in a backcross-derived breeding program. The theoretical contribution of L. hirsutum LA407 to each IBL is $12.5 \%$. Each line, therefore, contains $87.5 \%$ of the L. esculentum genome. Thus, LA407 and the IBL lines 2353 and 2361 described in this article represent new sources of resistance to C. michiganensis subsp. michiganensis that easily can be crossed with L. esculentum cultivars.

\section{ACKNOWLEDGMENTS}

We thank P. Turano for crosses used to develop the IBC population, T. Aldrich for technical assistance in planting and care of plants, and M. K. Hausbeck and D. W. Fulbright for their support and advice.

\section{LITERATURE CITED}

1. Alarcon, C., Castro, J., Munoz, F., Arce-Johnson, P., and Delgado, J. 1998. Protein(s) from the gram-positive bacterium Clavibacter michiganensis subsp. michiganensis induces a hypersensitive response in plants. Phytopathology 88:306-310.

2. Berry, S. Z., Madumadu, G. G., Uddin, M. R., and Coplin, D. L. 1989 Virulence studies and resistance to Clavibacter michiganensis ssp. michiganensis in tomato germplasm. HortScience 24:362-365.

3. Chong, R. J., Ries, S. M., and Pataky, J. K. 1992. Reductions in yield of processing tomatoes and incidence of bacterial canker. Plant Dis. 76:805-809.

4. Cotterill, P. P. 1987. On estimating heritability according to practical applications. Silvae Genet. 36:46-48

5. Emmatty, D. A., and John, C. A. 1973. Evaluation of resistance to bacterial canker of H2990, a new tomato variety. Plant Dis. Rep. 57:584-586

6. Emmatty, D. A., and John, C. A. 1973. Comparison of yield loss to bacterial canker of tomato in a resistant and a susceptible variety. Plant Dis. Rep. 57:787-788.

7. Eshed, Y., and Zamir, D. 1995. An introgression line population of Lycopersicon Pennellii in the cultivated tomato enables the identification and fine mapping of yieldassociated QTL. Genetics 141:1147-1162.

8. Eskridge, K. M., and D. P. Coyne. 1996. Estimating and Testing Hypotheses about the number of genes using inbred-backcross data. J. Hered. 87:410-412.

9. Gitaitis, R. 1990. Induction of a hypersensitive-like reaction in four o'clock by Clavibacter michiganensis subsp. michiganensis. Plant Dis. 74:58-60.

10. Gleason, M. L., Gitaitis, R. D., and Ricker, M. D. 1993. Recent progress in understanding in controlling bacterial canker of tomato in Eastern North America. Plant Dis. 77:1069-1076.

11. Hallauer, A. R., and Miranda, J. B. 1988. Quantitative Genetics in Maize Breeding, 2nd ed. Iowa State University Press, Ames.
12. Hausbeck, M. K., Bell, J., Medina-Mora, C., Podolsky, R., and Fulbright, D. W. 2000. Effect of bactericides on population sizes and spread of Clavibacter michiganensis subsp. michiganensis on tomatoes in the greenhouse and on disease development and crop yield in the field. Phytopathology 90:28-44.

13. Hibberd, A. M., Heaton, J. B., Finlay, G. P., and Dullahide, S. R. 1992. A greenhouse method for selecting tomato seedlings resistant to bacterial canker. Plant Dis. 76:1004 1007

14. Kabelka, E. A. 2000. Discovery and introgression of beneficial loci from Lycopersicon hirsutum, LA407, a wild species of tomato. $\mathrm{PhD}$ dissertation, Horticulture and Crop Science, The Ohio State University, Columbus.

15. Li, X., and DeBoer, S. H. 1994. Comparison of 16S ribrasomal RNA genes in Clavibacter michiganensis subspecies with other Coryneform bacteria. Can. J. Microbiol 41(10):92529.

16. Louws, F., Bell, J., Medina-Mora, C., Smart, C. D., Opgenorth, D., Ishimaru, C., deBruijn, F. R., Hausbeck, M., and Fulbright, D. W. 1998. Rep-PCR-mediated genomic fingerprinting: a rapid and effective method to identify Clavibacter michiganensis. Phytopathology 88: 862-868.

17. Louws, F. J., Fulbright, D. W., TaylorStephens, C, and DeBruijn, F. J. 1994. Specific genomic fingerprints of phytopathogenic Xanthomonas and pseudomonas pathovars and strains generated with repetitive sequences and PCR. Appl. Environ. Microbiol. 60(7):2286-2295

18. Louws, F. J., Fulbright, D. W., TaylorStephens, C, and DeBuijn, F. J. 1995. Differences of genomic structure by rep-PCR fingerprinting to rapidly classify Xanthomonas campestris pv. vesicatoria. Phytopathology 85(5):528-536.

19. Neter, J., Wasserman, W., and Kutner, M. H. 1990. Applied Linear Statistical Models, 3rd ed. Richard D. Irwin, Inc., Homewood, IL.

20. Pine T. S., Grogan, R. G., and Hewitt, W. B. 1955. Pathological anatomy of bacterial canker of young tomato plants. Phytopathology 45:267-271.

21. Poysa, V. 1993. Evaluation of tomato breeding lines resistant to bacterial canker. Can. J. Plant Pathol. 15:301-304.

22. Ricker, M. D., Emmaty, D. A., Schott, M. D., and Ozminkowski, R. H. 1996. Evaluation of three hybrids for resistance to Clavibacter mi- 
chiganensis subsp. michiganensis. (Abstr.) Phytopathology 86:S61

23. Ricker, M. D., and Reidel, R. M. 1993. Effect of secondary spread of Clavibacter michiganensis subsp. michiganensis on yield of Northern processing tomatoes. Plant Dis. 77:364-366

24. Rosenthal, S. A., and Cox, C. D. 1953. The somatic antigens of Corynebacterium michiganense and Corynebacterium insidiosum. J. Bacteriol. 65:532-537.

25. Rosenthal, S. A., and Cox, C. D. 1954. An antigenic analysis of some plant and soil Corynebacteria. Phytopathology 44:603-613.
26. Sandbrink, J. M., van Ooijen, J. W., Purimahua, C. C., Vrielink, M., Verkerk, R., Zabel, P., and Lindhout, P. 1995. Localization of genes for bacterial canker resistance in Lycopersicon peruvianum using RFLPs. Theor. Appl. Genet. 90:444-450.

27. Sotirova, V., and Bogatzevska, N. 1992. Sources of resistance to Clavibacter michiganensis subsp. michiganensis, Xanthomonas campestris pv. vesicatoria and Pseudomonas syringae pv. tomato in the Lycopersicon species. In: Plant Pathogenic Bacteria, Versailles ed. INRA, Paris.

28. Strider, D. L. 1969. Bacterial canker of to- mato, a literature review and bibliography. $\mathrm{N}$. C. Agric. Exp. Stn. Tech. Bull. 193.

29. VanHeusden, A. W., Koornneef, M., Voorrips, R. E., Bruggenmann, W., Pet, G., VrielinkvanGinkel, R., Chen, X., and Lindhout, P. 1999. Three QTLs from Lycopersicon peruvianum confer a high level of resistance to Clavibacter michiganensis ssp. michiganen sis. Theor. Appl. Genet. 99:1068-1074.

30. Werhan, C., and Allard, R. W. 1965. The detection and measurement of the effects of individual genes involved in the inheritance of a quantitative character in wheat. Genetics 51:109-119. 